\title{
Heterosis dan Heterobeltiosis Hasil Gabah Serta Korelasinya Terhadap Pertumbuhan Padi Hibrida
}

\author{
Heterosis and Heterobeltiosis of Grain Yield and their Correlation to Hybrid Rice Growth \\ Nurwulan Agustiani, Sujinah*, Bayu P. Wibowo, Satoto
}

Balai Besar Penelitian Tanaman Padi, Jl. Raya 9 Sukamandi, Subang, Jawa Barat

*E-mail Penulis Korespondensi: sujinahsulaiman26@gmail.com

\begin{abstract}
Heterosis of F1 hybrids is closely related to processes during plant growth. The purpose of this research was to obtain information on some growth characters that supported positive heterosis for yield. The experiment was conducted at Sukamandi Field Station on the rainy season in 2016, used a Randomized Complete Block Design with three replications. The materials used in this experiment were four hybrids rice (Hipa 9, Hipa 18, Hipa 19, and Hipa Jatim 2) and their parents (maintainer and restorer lines). The results showed that the four hybrids had positive heterosis with an average value of 4.23-25.03\% for the characters of plant height, tiller number, grain number per panicle, weight of 1000 grains, and yield. Heterobeltiosis values ranged from 2.06-13.62\% for the characters of plant height, tiller number, grain number per panicle, and yield. The characters that were positively correlated to increase of yield were plant height, leaf area in the primordia phase, and weight of 1000 grains. The four hybrids had similar leaf areas in the primordia phase, but only Hipa Jatim 2 had the highest leaf area in the mature grain. The four hybrids had more thickness of leaves than their parents. F1 average showed increased grain number per panicle that their parents, especially Hipa 18 and Hipa 19, which had a higher weight of 1000 grains than their parents.
\end{abstract}

Keywords: hybrids, rice, heterosis, heterobeltiosis

\section{ABSTRAK}

Heterosis pada F1-hibrida sangat berkaitan erat dengan proses-proses selama pertumbuhan tanaman. Tujuan penelitian ini adalah untuk mendapatkan informasi beberapa karakter pertumbuhan yang mendukung heterosis positif terhadap hasil. Percobaan dilaksanakan di KP. Sukamandi pada musim hujan 2016, menggunakan Rancangan Acak Kelompok dengan tiga ulangan. Materi yang digunakan dalam penelitian ini adalah empat varietas unggul hibrida (Hipa 9, Hipa 18, Hipa 19, dan Hipa Jatim 2) dan tetuanya (galur maintainer dan restorer). Hasil penelitian menunjukkan bahwa keempat materi yang diuji mempunyai nilai heterosis positif dengan nilai rata-rata 4,23-25,03\% pada karakter tinggi tanaman, jumlah anakan, jumlah gabah per malai, bobot 1000 butir, dan hasil. Nilai heterobeltiosis berkisar antara 2,06\% sampai $13,62 \%$ pada karakter tinggi tanaman, jumlah anakan, jumlah gabah per malai, dan hasil. Karakter-karakter pertumbuhan yang berkorelasi positif terhadap peningkatan hasil yaitu tinggi tanaman, luas daun pada fase primordia, dan bobot 1000 butir. Keempat materi hibrida yang diuji mempunyai luas daun per rumpun yang setara pada fase primordia, namun hanya Hipa Jatim 2 yang masih mempunyai luas daun tertinggi pada fase masak fisiologis. Keempatnya mempunyai karakter ketebalan daun yang lebih baik dibanding tetuanya. Rata-rata F1 mempunyai perbaikan jumlah gabah per malai dibanding kedua tetuanya, terlebih pada Hipa 18 dan Hipa 19 yang juga mempunyai bobot 1000 butir lebih tinggi dari kedua tetuanya.

Kata kunci: hibrida, padi, heterosis, heterobeltiosis

\section{PENDAHULUAN}

Padi hibrida sejak lebih dari 20 tahun yang lalu telah dilaporkan mampu memberikan hasil $20 \%$ lebih tinggi dibandingkan padi biasa (Lin dan Yuan, 1980). Berbagai pengujian menunjukkan bahwa padi hibrida di Indonesia memiliki keunggulan heterosis daya hasil 10$25 \%$ lebih tinggi dibanding varietas padi unggul inbrida yang populer saat ini, seperti Ciherang, Mekongga, IR64 dan lain-lain (Satoto et al., 2010; Widyastuti dan Satoto, 2012). Penyerbukan silang pada dua tanaman padi yang berbeda untuk menghasilkan benih hibrida di Indonesia hanya dimungkinkan jika bunga jantan pada tanaman betina bersifat mandul atau dibuat tidak berfungsi yang dapat dibuat dengan cara memasukkan gen cms (cytoplasmic male sterility). Penggunaan gen $\mathrm{cms}$ ini 
mengharuskan perakitan varietas padi hibrida menggunakan tiga galur, yaitu Galur Mandul Jantan (GMJ) atau CMS (galur A), galur pelestari atau maintainer (galur B), dan tetua jantan yang sekaligus berfungsi sebagai pemulih kesuburan atau restorer (galur R).

Perakitan atau pemuliaan tanaman hibrida dilandasi oleh adanya fenomena heterobeltiosis dan heterosis yaitu suatu kondisi bahwa $\mathrm{F}_{1}$ akan tampil lebih baik dibandingkan dengan salah satu atau rata-rata kedua tetuanya. Zhi-Yuan et al. (2015) mendefinisikan heterosis merupakan sifat hibrida yang menunjukkan fenotipe lebih unggul dari induknya baik dari karakter peningkatan biomassa, pertumbuhan, hasil, dan toleransi cekaman. Saidaiah et al. (2012) menyatakan penyebab suatu sifat akan mengalami heterosis apabila salah satu induk yang terlibat dalam persilangan memiliki karakter yang lebih dominan. Ada dua hipotesis yang memberi penjelasan gejala heterosis, yaitu hipotesis dominan dan hipotesis over dominan. Padi hibrida dapat meningkatkan 15-30\% dibanding varietas inbrida (Peng et al., 1999). Hasil penelitian Kartina et al. (2017), terdapat 31 calon varietas padi hibrida yang memiliki nilai standar heterosis $10-51 \%$ lebih tinggi dari varietas pembanding. Penelitian ini bertujuan untuk mengetahui beberapa karakter pertumbuhan tanaman yang mendukung pencapaian heterosis positif terhadap hasil.

\section{BAHAN DAN METODE}

Percobaan dilaksanakan di KP Sukamandi, Ciasem, Subang mulai bulan Juni sampai September 2016. Rancangan yang digunakan adalah rancangan kelompok lengkap teracak dengan tiga ulangan. Materi yang digunakan dalam percobaan ini adalah 4 varietas unggul hibrida (Hipa 9, Hipa 18, Hipa 19, dan Hipa Jatim 2), yang terdiri dari individu hibrida (F1), galur maintainer (B), dan galur restorer (R). Pengolahan tanah pertama dengan bajak, kemudian dilanjutkan dengan perbaikan petakan dan pelumpuran tanah menggunakan cangkul. Ukuran tiap petak perlakuan adalah $5 \times 6 \mathrm{~m}$. Bibit padi ditanam pada umur 21 hari setelah sebar (hss) dengan jumlah 2-3 bibit/lubang. Gulma dikendalikan secara manual, yaitu pada umur 21 dan 42 hari setelah tanam. Pencegahan hama dan penyakit dilakukan dengan pemberian karbofuran dengan dosis $17 \mathrm{~kg} / \mathrm{ha}$, sedangkan untuk pengendaliannya menggunakan insektisida yang direkomendasikan sesuai dengan hama sasaran. Panen dilakukan pada saat malai menguning $90 \%$, kemudian diambil sampel sebanyak 12 rumpun per plot untuk data komponen hasil sedangkan data ubinan diambil dari sampel tanaman 120 rumpun dan dikonversi ke ha dengan kadar air $14 \%$.

Tabel 1. Heterobeltiosis dan heterosis tinggi tanaman padi hibrida

\begin{tabular}{|c|c|c|c|c|c|}
\hline \multirow{2}{*}{ Keterangan } & \multicolumn{5}{|c|}{ Tinggi tanaman $(\mathrm{cm})$} \\
\hline & $14 \mathrm{hst}$ & $28 \mathrm{hst}$ & 42 hst & 56 hst & Sblm panen \\
\hline \multicolumn{6}{|l|}{ Hipa 9} \\
\hline B & 41,75 & 60,42 & 79,38 & 95,17 & 105,67 \\
\hline $\mathrm{R}$ & 41,88 & 61,29 & 76,50 & 106,71 & 104,79 \\
\hline $\mathrm{F} 1$ & 42,21 & 64,21 & 85,08 & 108,83 & 116,54 \\
\hline Heterobeltiosis & 0,80 & 4,76 & 7,19 & 1,99 & 10,29 \\
\hline Heterosis & 0,95 & 5,51 & 9,17 & 7,82 & 10,75 \\
\hline \multicolumn{6}{|l|}{ Hipa 18} \\
\hline B & 40,17 & 63,04 & 86,38 & 109,00 & 118,63 \\
\hline $\mathrm{R}$ & 42,46 & 63,88 & 86,71 & 97,71 & 110,83 \\
\hline F1 & 45,63 & 67,29 & 89,96 & 109,67 & 123,71 \\
\hline Heterobeltiosis & 7,46 & 5,35 & 3,75 & 0,61 & 4,29 \\
\hline Heterosis & 10,44 & 6,04 & 3,95 & 6,11 & 7,83 \\
\hline \multicolumn{6}{|l|}{ Hipa 19} \\
\hline B & 41,25 & 63,00 & 88,08 & 108,50 & 116,92 \\
\hline $\mathrm{R}$ & 40,04 & 59,96 & 78,83 & 98,25 & 124,42 \\
\hline $\mathrm{F} 1$ & 40,79 & 64,08 & 86,08 & 113,63 & 123,75 \\
\hline Heterobeltiosis & $-1,11$ & 1,72 & $-2,27$ & 4,72 & $-0,54$ \\
\hline Heterosis & 0,36 & 4,24 & 3,15 & 9,92 & 2,56 \\
\hline \multicolumn{6}{|l|}{ Hipa Jatim 2} \\
\hline B & 38,83 & 58,08 & 76,08 & 93,04 & 101,58 \\
\hline $\mathrm{R}$ & 43,29 & 69,83 & 92,38 & 107,25 & 124,33 \\
\hline $\mathrm{F} 1$ & 45,25 & 71,17 & 93,96 & 108,21 & 122,08 \\
\hline Heterobeltiosis & 4,52 & 1,91 & 1,71 & 0,89 & $-1,81$ \\
\hline Heterosis & 10,20 & 11,27 & 11,55 & 8,05 & 8,08 \\
\hline \multicolumn{6}{|l|}{ Rata-rata } \\
\hline Heterobeltiosis & 2,92 & 3,43 & 2,60 & 2,06 & 3,06 \\
\hline Heterosis & 5,49 & 6,76 & 6,95 & 7,97 & 7,30 \\
\hline $\mathrm{P}$ value & 2,19 & $4,75^{* *}$ & $10,73^{* *}$ & $9,37^{* *}$ & $50,92^{* *}$ \\
\hline
\end{tabular}

Keterangan: $\mathrm{B}=$ galur maintainer, $\mathrm{R}=$ galur restorer, $\mathrm{F} 1=$ Hibrida 
Tabel 2. Heterobeltiosis dan heterosis jumlah anakan padi hibrida

\begin{tabular}{|c|c|c|c|c|c|}
\hline \multirow{2}{*}{ Keterangan } & \multicolumn{5}{|c|}{ Jumlah anakan/rumpun } \\
\hline & 14 hst & $28 \mathrm{hst}$ & $42 \mathrm{hst}$ & $56 \mathrm{hst}$ & Sblm panen \\
\hline \multicolumn{6}{|l|}{ Hipa 9} \\
\hline B & 10,08 & 18,04 & 25,17 & 15,25 & 13,88 \\
\hline $\mathrm{R}$ & 8,96 & 21,33 & 25,33 & 19,21 & 15,29 \\
\hline F1 & 10,46 & 22,13 & 25,50 & 18,42 & 14,71 \\
\hline Heterobeltiosis & 3,72 & 3,71 & 0,66 & $-4,12$ & $-3,81$ \\
\hline Heterosis & 9,85 & 12,38 & 0,99 & 6,89 & 0,86 \\
\hline \multicolumn{6}{|l|}{ Hipa 18} \\
\hline B & 10,42 & 22,08 & 26,42 & 19,46 & 16,96 \\
\hline $\mathrm{R}$ & 8,46 & 19,96 & 26,33 & 18,67 & 17,00 \\
\hline $\mathrm{F} 1$ & 10,83 & 22,83 & 26,21 & 18,29 & 16,58 \\
\hline Heterobeltiosis & 4,00 & 3,40 & $-0,79$ & $-6,00$ & $-2,45$ \\
\hline Heterosis & 14,79 & 8,62 & $-0,63$ & $-4,04$ & $-2,33$ \\
\hline \multicolumn{6}{|l|}{ Hipa 19} \\
\hline B & 9,75 & 22,38 & 27,04 & 19,25 & 16,63 \\
\hline $\mathrm{R}$ & 10,42 & 20,63 & 26,67 & 18,08 & 16,25 \\
\hline $\mathrm{F} 1$ & 10,50 & 22,75 & 25,63 & 17,13 & 16,04 \\
\hline Heterobeltiosis & 0,80 & 1,68 & $-5,24$ & $-11,04$ & $-3,51$ \\
\hline Heterosis & 4,13 & 5,81 & $-4,58$ & $-8,26$ & $-2,41$ \\
\hline \multicolumn{6}{|l|}{ Hipa Jatim 2} \\
\hline $\mathrm{B}$ & 8,33 & 17,63 & 24,79 & 18,04 & 15,75 \\
\hline $\mathrm{R}$ & 7,58 & 14,96 & 17,63 & 14,46 & 13,63 \\
\hline $\mathrm{F} 1$ & 10,17 & 19,33 & 21,33 & 16,33 & 14,25 \\
\hline Heterobeltiosis & 22,00 & 9,69 & $-13,95$ & $-9,47$ & $-9,52$ \\
\hline Heterosis & 27,58 & 18,67 & 0,59 & 0,51 & $-2,98$ \\
\hline \multicolumn{6}{|l|}{ Rata-rata } \\
\hline Heterobeltiosis & 7,63 & 4,62 & $-4,83$ & $-7,66$ & $-4,82$ \\
\hline Heterosis & 14,13 & 11,37 & $-0,91$ & $-1,22$ & $-1,72$ \\
\hline$P$ value & 1,83 & $4,51^{* *}$ & $6,18^{* *}$ & $4,84^{* *}$ & 1,85 \\
\hline
\end{tabular}

Keterangan: $\mathrm{B}$ = galur maintainer, $\mathrm{R}=$ galur restorer, $\mathrm{F} 1=$ Hibrida

Variabel pengamatan yang dilakukan adalah sebagai berikut: 1) Komponen pertumbuhan: tinggi tanaman, jumlah anakan per rumpun, kehijauan daun dengan menggunakan SPAD Minolta 502, luas daun, dan bobot daun khas; dan 2) Komponen hasil: jumlah malai per rumpun, jumlah gabah per malai, persen gabah isi, bobot 1000 butir, dan hasil ubinan per plot.

Data yang terkumpul dianalisis keragamannya dan dilanjutkan dengan analisis korelasi (Pearson) untuk mengetahui korelasi antar variabel terhadap hasil. Datadata dihitung nilai heterobeltiosis dan heterosis. Rumus yang digunakan untuk menghitung nilai heterobeltiosis dan heterosis menggunakan rumus Virmani et al. (1997) yaitu sebagai berikut:

$$
\begin{gathered}
\text { Heterobeltiosis }=\frac{F 1 \text { hibrida }- \text { tetua terbaik }}{\text { Tetua terbaik }} \times 100 \% \\
\text { Heterosis }=\frac{F 1 \text { hibrida }- \text { rerata tetua }}{\text { Rerata } \text { tetua }} \times 100 \%
\end{gathered}
$$

\section{HASIL DAN PEMBAHASAN}

\section{Pertumbuhan Tanaman}

Postur tanaman keempat varietas baik tetua (B dan R) maupun F1 tertera pada Tabel 1. Tinggi tanaman individu F1 Hipa 9 dan Hipa 18 lebih tinggi dibanding kedua induknya, namun F1 Hipa 19 dan Hipa Jatim 2 lebih tinggi dari galur maintener tetapi lebih pendek dari galur restorer. Lebih rendahnya tinggi tanaman individu F1 tersebut dibanding induknya menyebabkan nilai heterobeltiosis negatif. Rata-rata nilai heterosis terendah terdapat pada Hipa 19 sedangkan nilai heterosis tertinggi terdapat pada Hipa Jatim 2. Semua individu F1 dari keempat varietas memiliki nilai heterosis positif dengan kisaran 5-7\%. Hasil yang sama diperoleh pada penelitian Joshi (2003) dimana heterosis positif terdapat pada karakter tinggi tanaman yang dapat mencapai nilai heterosis 62. Hasil berbeda didapatkan pada penelitian Tiwari et al. (2011), sebagian besar tanaman hibrida yang diuji, yaitu 53 dari 60 hibrida memiliki nilai heterosis negatif, yang berarti kecenderungan tanaman hibrida memiliki postur tanaman yang lebih pendek.

Kemampuan pembentukan anakan sangat erat kaitannya dengan source suatu tanaman. Rata-rata jumlah anakan tanaman hibrida yang diuji adalah 14 anakan per rumpun, dan hal ini termasuk dalam kategori sedang (IRRI, 2013). Pada Tabel 2 terlihat nilai heterobeltiosis dan heterosis jumlah anakan dari keempat varietas hibrida yang diuji. Nilai heterobeltiosis bersifat negatif mulai umur 42 hst sedangkan di awal pertumbuhan bersifat positif. Nilai heterosis juga bersifat negatif setelah umur 42 hst pada varietas Hipa 18, 19, dan Jatim 2. Rata-rata nilai heterosis di bawah $10 \%$ kecuali di awal pertumbuhan. Hasil ini jauh berbeda dengan penelitian Thorat et al. (2017) dimana nilai heterosis untuk karakter jumlah anakan berkisar $20-60 \%$. Nilai 
heterobeltiosis dan heterosis dapat bersifat negatif dan positif, tergantung tujuan pemulia (Rahimi et al., 2010). Nilai heterosis hibrida yang lebih tinggi dimungkinkan memiliki jarak genetik yang lebih jauh dengan tetuanya (Sholekha et al., 2015).

Nilai kehijauan daun galur restorer di awal pertumbuhan terlihat lebih rendah dibanding galur maintainer ataupun hibridanya. Secara umum, kehijaun daun tanaman hibrida lebih rendah dari tetuanya (Gambar 1). Pada Hipa 18, galur restorer mempunyai tingkat kehijauan daun terendah dibanding galur maintainer maupun hibridanya. Nilai kehijauan daun pada semua fase pengamatan masih di atas batas kritis, yaitu 36. Hal ini menunjukkan bahwa semua tanaman masih berada dalam batas kecukupan nitrogen. Diantara keempat hibrida yang diuji sampai umur 56 hst, Hipa 9 dan Hipa 19 mempunyai nilai SPAD rata-rata 42, sedikit lebih tinggi dibanding Hipa 18 dan Hipa Jatim 2 dengan rata-rata 40. Hipa Jatim 2 mempunyai karakter kehijauan daun yang mirip karakter galur restorernya, meskipun masih di bawah galur maintainer. Perbaikan karakter ini diduga dapat memberikan kontribusi terhadap laju asimilasi bersih yang berdampak pada peningkatan cadangan asimilat khususnya pada fase pengisian. Daun yang tua/menguning mengindikasikan adanya proses perombakan klorofil dan menurunnya fungsi kloroplas sehingga proses fotosintesa untuk menghasilkan asimilat sebagai energi bagi tanaman menurun, hal ini juga akan

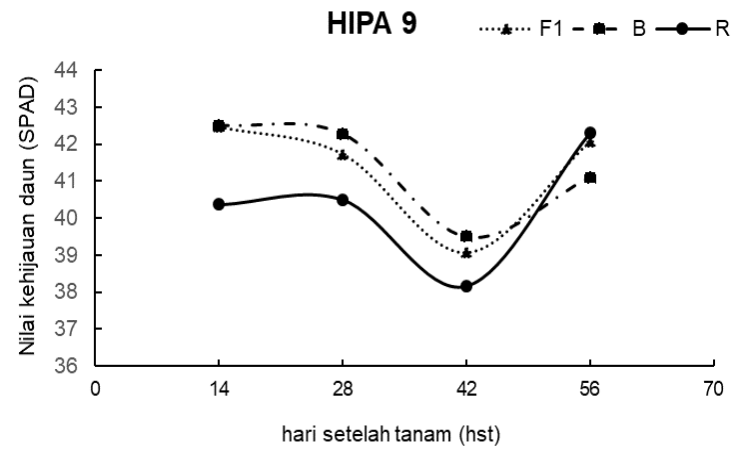

HIPA 19

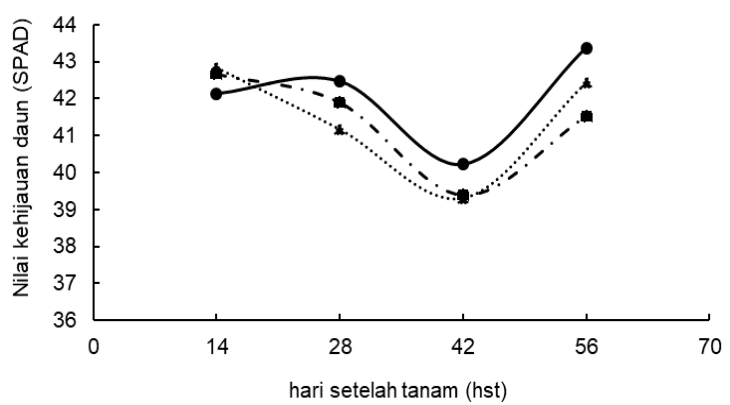

berpengaruh terhadap tidak optimalnya proses pengisian gabah. Oleh karena itu, semakin cepat daun menguning maka akan berpengaruh terhadap pengisian gabah yang tidak optimal sehingga dapat meningkatkan persentase kehampaan gabah. Kehijauan daun berhubungan dengan kandungan klorofil per luas daun pada tanaman monokotil dan dikotil, namun hubungan tersebut ada yang linier dan non linier (Peng et al., 1996; Xiong et al., 2015).

\section{Luas Daun dan Bobot Daun Khas}

Keempat varietas yang diuji memiliki luas daun dengan pola yang hampir sama (Gambar 2). Namun demikian, hanya Hipa Jatim 2 yang masih mempunyai luas daun tertinggi pada fase masak fisiologis. Galur restorer pada Hipa 9, Hipa 18, Hipa 19, dan Hipa Jatim 2 memiliki luas daun yang tertinggi dibanding galur maintainer ataupun hibrida. Pada Hipa 18, luas daun galur maintener dan hibrida relatif sama, namun pada fase masak fisiologis, luas daun hibrida lebih rendah dibanding galur maintainer. Daun merupakan organ penting dalam proses fotosintesis. Daun mempengaruhi produksi bahan kering tanaman melalui intersepsi cahaya pada awal dan akhir pertumbuhan (Gardner et al., 1985). Selain itu, peningkatan laju fotosintesis daun digunakan sebagai metode dalam peningkatan hasil (Horton, 2000; Hubbart et al., 2007).

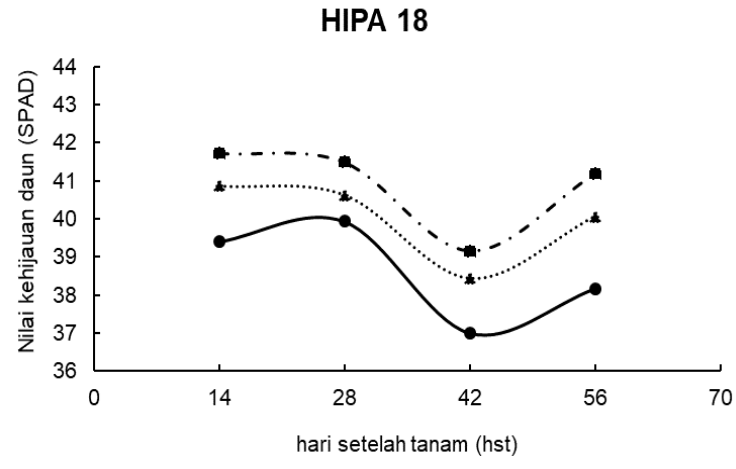

HIPA JATIM 2

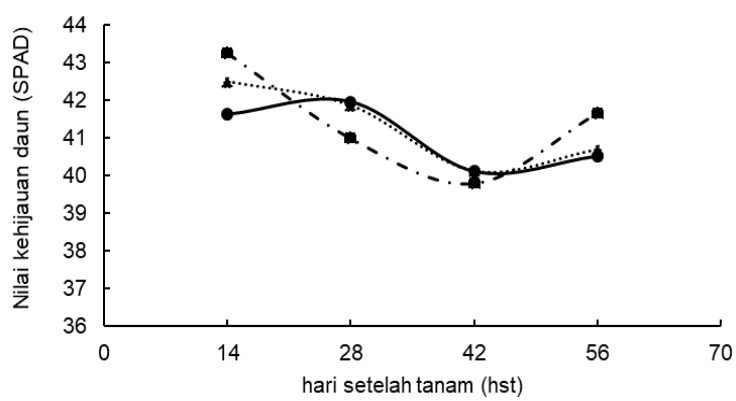

Gambar 1. Hasil nilai kehijauan dengan (SPAD) pada individu F1 (hibrida), B (galur maintener), dan R (galur restorer) pada beberapa varietas hibrida 


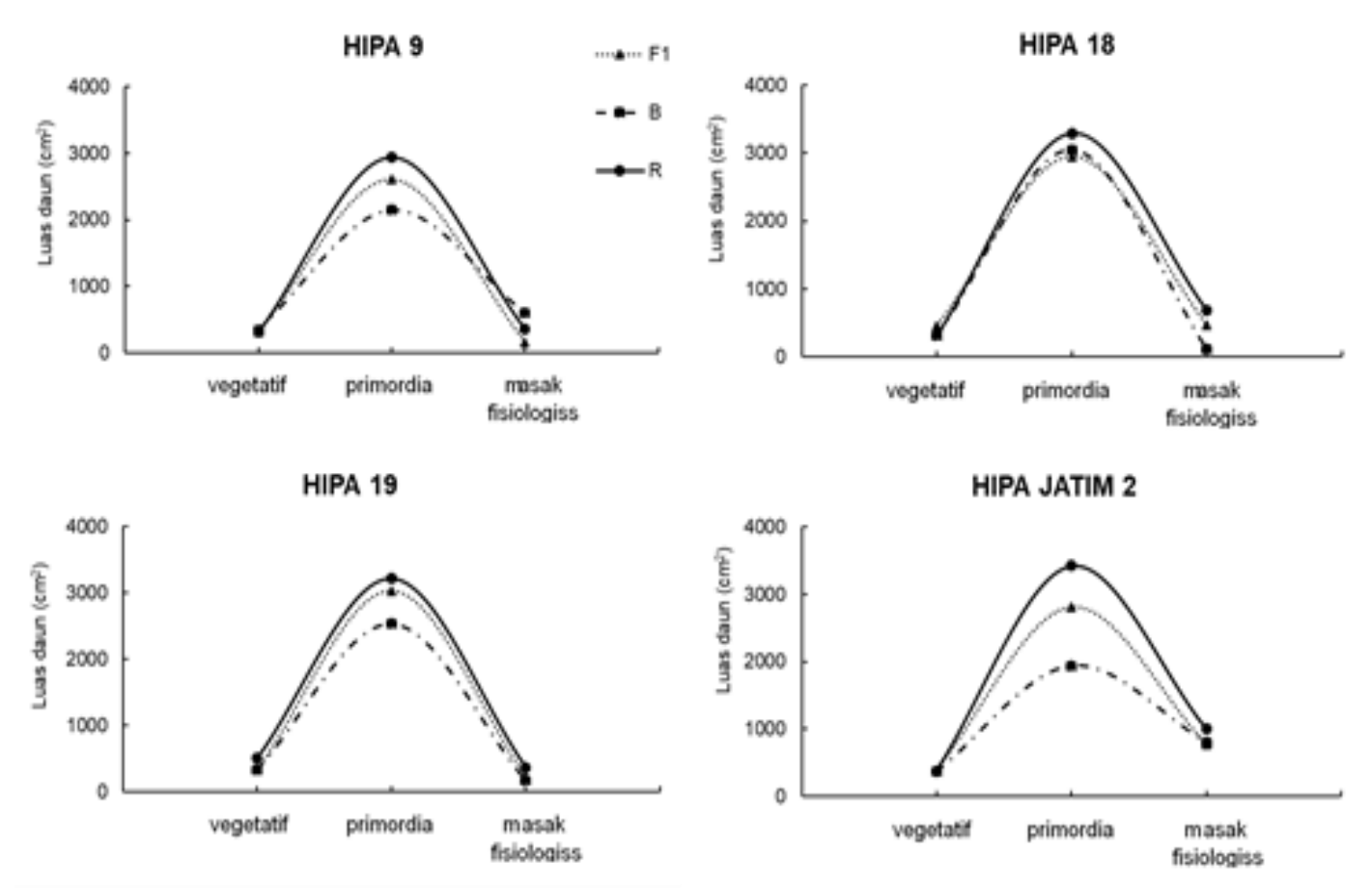

Gambar 2. Luas daun pada individu F1 (hibrida), B (galur maintener), dan R (galur restorer) pada beberapa varietas hibrida

Bobot daun khas merupakan hasil pembagian luas daun dengan berat daun. Indeks ini mengandung informasi ketebalan daun yang dapat mencerminkan unit organela fotosintesis. Lebar dan ketebalan daun mempunyai korelasi dengan jumlah kloroplas yang dimiliki sebagai gerbang masuk input-input produksi pada proses fotosintesis. Berdasarkan analisa ketebalan daun, tanaman hibrida Hipa 9 dan Hipa 19 secara genetik mempunyai daun yang lebih tebal dibanding Hipa 18 dan Hipa Jatim 2 dimana perubahan ini terlihat ketika tanaman pada fase masak fisiologis. Sementara itu, selain Hipa 18, ketiga tanaman hibrida mampu menunjukkan ketebalan daun yang lebih baik dibanding kedua tetuanya (Gambar 3). Ketebalan daun ini berkaitan dengan sensitivitas tanaman terhadap intensitas cahaya. Intensitas cahaya tinggi menyebabkan sel-sel daun lebih kecil, tilakoid mengumpul, dan klorofil lebih sedikit, sehingga ukuran daun lebih kecil dan tebal (Buntoro et al., 2014). Ketebalan daun berkorelasi positif dengan panjang dan lebar daun, dan hal ini menunjukkan bahwa ketebalan daun dapat meningkatkan luas daun secara tunggal (Liu et al., 2014).

\section{Komponen hasil dan hasil}

Komponen hasil galur maintainer, restorer, dan hibrida F1 empat varietas hibrida yang diuji tertera pada Tabel 3. Ketiga hibrida F1 dari Hipa 9, Hipa 19, dan Hipa Jatim 2 memiliki jumlah malai per rumpun lebih sedikit dibanding rata-rata tetuanya. Hibrida F1 Hipa 18 mempunyai jumlah malai terbanyak $(16,36)$ dibanding ketiga varietas hibrida yang lain. Jumlah gabah per malai hibrida F1 dari keempat varietas hibrida yang diuji lebih banyak dibanding kedua tetuanya. Keempat hibrida F1 mempunyai jumlah gabah per malai dengan kisaran 157,40-199,30. Kartina et al. (2014) menyatakan tingginya jumlah gabah per malai menunjukkan tanaman mempunyai sifat pembungaan yang baik. Berbeda dengan karakter jumlah gabah per malai, persentase gabah isi menunjukkan sebaliknya. Persentase gabah isi F1 keempat varietas hibrida lebih rendah dibanding tetuanya. Nilai persentase gabah isi di bawah $70 \%$ (hibrida F1 Hipa 9 : 59,12; Hipa 18 : 69,96; Hipa 19 : 67,93; Hipa Jatim 2 : 61,94). Rendahnya pengisian gabah kemungkinan disebabkan oleh inkompatibitas antara tetua maintainer dan restorer. Pada umumnya inkompatibilitas antara galur maintainer dan restorer pada varietas hibrida terjadi pada perakitan varietas dengan menggunakan tiga galur. Bobot 1000 butir dari hibrida F1 berkisar 20,82-23,18 gram. Ketiga hibrida F1 (Hipa 9, Hipa 18, dan Hipa Jatim 2) memiliki bobot 1000 butir lebih besar dari tetua maintainer tetapi lebih kecil dari tetua restorer.

Hasil penelitian menunjukkan bahwa Hipa 18 dan Hipa Jatim 2 memiliki nilai heterosis positif untuk ketiga karakter komponen hasil, yaitu jumlah malai per rumpun, jumlah gabah per malai, dan bobot 1000 butir. Selain itu, Hipa 18 memiliki nilai heterobeltiosis positif pada karakter jumlah malai per rumpun dan jumlah gabah per malai. Nilai heterosis dan heterobeltiosis positif Hipa 18 pada karakter tersebut menunjukkan bahwa hibrida F1 lebih bagus dari tetuanya. Nilai heterobeltiosis dan heterosis positif pada Hipa 19 terdapat pada karakter jumlah gabah per malai dan bobot 1000 butir. Hipa 9 dan Hipa Jatim 2 memiliki nilai heterobeltiosis negatif pada karakter jumlah malai per rumpun, persentase gabah isi, dan bobot 1000 butir. 

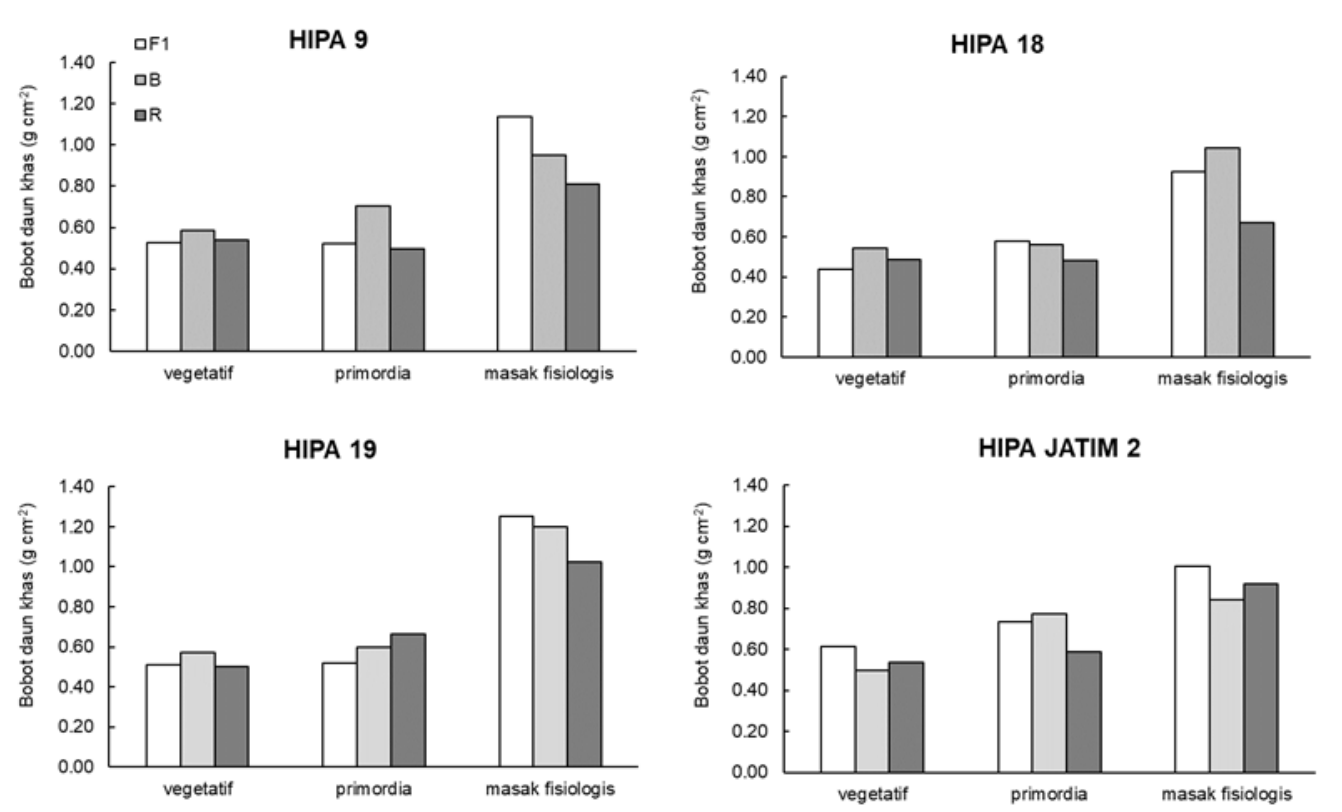

Gambar 3. Bobot daun khas pada individu F1 (hibrida), B (galur maintener), dan R (galur restorer) pada beberapa varietas hibrida

Tabel 3. Heterobeltiosis dan heterosis komponen hasil beberapa varietas hibrida

\begin{tabular}{lccccc}
\hline Keterangan & $\begin{array}{c}\text { Jmlh } \\
\text { malai/rmp }\end{array}$ & $\begin{array}{c}\text { Jmlh } \\
\text { gabah/malai }\end{array}$ & $\begin{array}{c}\text { Persentase } \\
\text { gabah isi }\end{array}$ & $\begin{array}{c}\text { Bobot } 1000 \\
\text { butir }\end{array}$ & $\begin{array}{c}\text { Hasil GKG } \\
\text { (t/ha) }\end{array}$ \\
\hline Hipa 9 & & & & & \\
B & 13,03 & 151,42 & 74,95 & 20,17 & 5,07 \\
R & 16,67 & 114,21 & 75,46 & 24,86 & 6,95 \\
F1 & 13,83 & 157,40 & 59,12 & 23,18 & 6,17 \\
Heterobeltiosis & $-17,00$ & 3,95 & $-21,66$ & $-6,78$ & $-11,22$ \\
Heterosis & $-6,83$ & 18,51 & $-21,39$ & 2,94 & 2,68 \\
Hipa 18 & & & & & \\
B & 14,89 & 137,24 & 71,82 & 20,25 & 6,43 \\
R & 14,69 & 112,70 & 78,12 & 22,49 & 6,00 \\
F1 & 16,36 & 159,69 & 69,96 & 22,33 & 6,64 \\
Heterobeltiosis & 9,89 & 16,36 & $-10,45$ & $-0,71$ & 3,32 \\
Heterosis & 10,61 & 27,79 & $-6,69$ & 4,49 & 6,85 \\
Hipa 19 & & & & & \\
B & 13,58 & 135,01 & 66,59 & 20,05 & 5,82 \\
R & 15,47 & 171,56 & 71,04 & 19,60 & 5,47 \\
F1 & 13,89 & 199,30 & 67,93 & 20,82 & 6,53 \\
Heterobeltiosis & $-10,23$ & 16,17 & $-4,38$ & 3,84 & 12,29 \\
Heterosis & $-4,40$ & 30,02 & $-1,29$ & 5,02 & 15,75 \\
Hipa Jatim 2 & 13,86 & 151,58 & 68,78 & 17,46 & 5,00 \\
B & 11,56 & 137,31 & 77,19 & 26,80 & 6,37 \\
R & 12,72 & 178,85 & 61,94 & 23,12 & 7,05 \\
F1 & $-8,22$ & 17,99 & $-19,76$ & $-13,72$ & 10,75 \\
Heterobeltiosis & 0,11 & 23,82 & $-15,14$ & 4,48 & 24,04 \\
Heterosis & & & & & \\
\hline Rata-rata & $-6,39$ & 13,62 & $-14,06$ & $-4,34$ & 3,79 \\
Heterobeltiosis & $-0,13$ & 25,03 & $-11,13$ & 4,23 & 12,33 \\
Heterosis & 1,66 & $6,02^{* *}$ & $3,21^{* *}$ & $13,42^{* *}$ & $7,99^{* *}$ \\
\hline P value
\end{tabular}

Keterangan: $\mathrm{B}=$ galur maintainer, $\mathrm{R}=$ galur restorer, $\mathrm{F} 1=$ Hibrida 


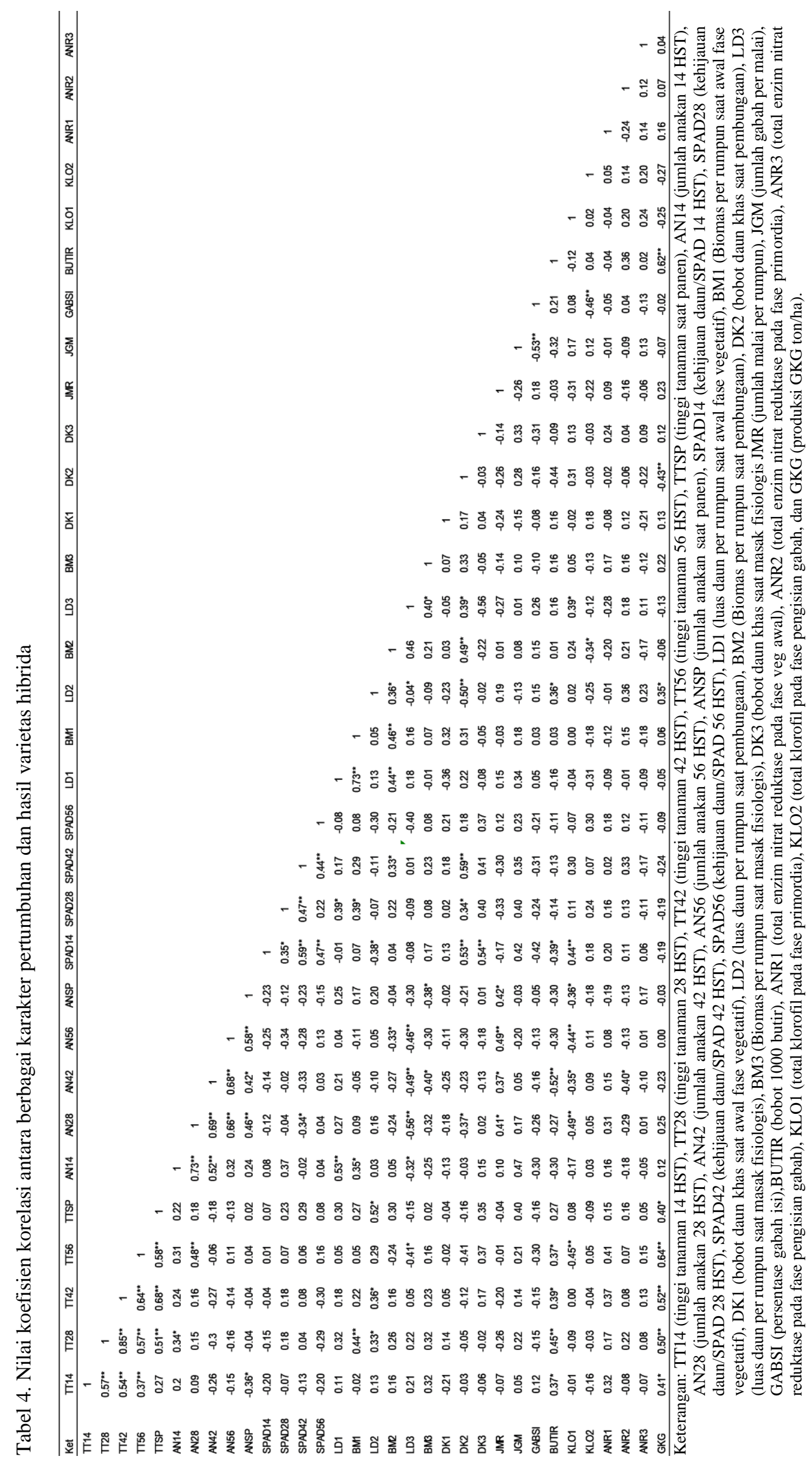


Hasil gabah merupakan karakter yang bersifat kompleks, ekspresinya dipengaruhi oleh beberapa karakter lainnya. Hasil gabah dari tanaman galur maintainer, restorer, dan F1 hibrida berkisar 5-7 ton/ha. Hasil gabah F1 Hipa Jatim 2 lebih baik daripada ketiga F1 varietas hibrida yang lain. Ketiga F1 hibrida (Hipa 18, Hipa 19, dan Hipa Jatim 2) mampu menghasilkan produksi melebihi kedua tetuanya sedangkan F1 Hipa 9 menghasilkan produksi yang lebih besar dari galur maintainer tetapi lebih rendah dari galur restorernya. Hal ini menyebabkan nilai heterobeltiosis Hipa 9 bersifat negatif. Nilai heterobeltiosis keempat ketiga varietas hibrida (Hipa 18, Hipa 19, dan Hipa Jatim 2) bersifat positif dengan kisaran 3-12, sedangkan untuk Hipa 8 bersifat negatif. Nilai heterosis varietas hibrida bersifat positif, dimana Hipa Jatim 2 memiliki nilai heterosis terbesar (24,04\%). Menurut Joshi (2003), F1 hibrida yang memiliki nilai heterobeltiosis lebih dari $20 \%$ untuk karakter hasil dapat digunakan untuk produksi benih hibrida, yang didukung juga oleh karakter agronomi lain, seperti kemasakan biji, tinggi tanaman, dan kualitas biji.

\section{Korelasi terhadap hasil}

Hasil analisis korelasi menunjukkan bahwa variabel-variabel yang berpengaruh nyata terhadap peningkatan hasil yaitu tinggi tanaman, luas daun fase primordia, bobot daun khas/ketebalan daun pada fase primordia, dan bobot 1000 butir (Lampiran 1). Koefisien korelasi dengan angka positif menunjukkan bahwa peningkatan karakter yang satu akan diikuti oleh peningkatan karakter lain. Peningkatan hasil berbanding lurus dengan peningkatan tinggi tanaman sejak awal pertumbuhan hingga panen dan luas daun pada fase primordia, namun berbanding terbalik dengan peningkatan bobot daun khas/ketebalan daun pada fase yang sama. Ntanos dan Koutroubas (2002) menjelaskan bahwa karakter agronomis khususnya umur dan postur tinggi tanaman mempunyai pengaruh signifikan terhadap translokasi asimilat. Semakin panjang umur tanaman semakin banyak asimilat yang mampu disimpan, demikian juga pada tanaman dengan postur lebih tinggi. Sementara itu, translokasi dari bagian batang dapat mencapai $40 \%$ dari ketercapaian hasil tergantung interaksi antara genotipe dan lingkungan (Yoshida, 1972). Lebih lanjut lagi, diketahui bahwa pembentukan tinggi tanaman mempunyai korelasi nyata dengan pembentukan anakan, luas daun, biomas tanaman, laju asimilasi bersih, dan aktivitas nitrat reductase. Translokasi asimilat ini muncul dalam variabel hasil utamanya dalam bentuk bobot 1000 butir gabah yang nyata berpengaruh positif terhadap hasil.

\section{KESIMPULAN}

Varietas hibrida yang diuji memiliki hasil yang lebih tinggi dari rata-rata tetuanya, hal ini terlihat dari nilai heterosis dan heterobeltiosis yang bersifat positif kecuali pada Hipa 9. Hipa Jatim 2 mampu memberikan hasil tertinggi dibanding hibrida lainnya. Karakter- karakter pertumbuhan yang berkorelasi positif dengan hasil yaitu tinggi tanaman, luas daun pada fase primordia, dan bobot 1000 butir, sedangkan karakter bobot daun khas fase primordia berkorelasi negatif.

\section{DAFTAR PUSTAKA}

Buntoro, B.H., R. Rogomulyo, dan S. Trisnowati. 2014. Pengaruh takaran pupuk kandang dan intensitas cahaya terhadap pertumbuhan dan hasil temu putih (Curcuma zedoaria L.). Vegetalika 3: 2939.

Gardner, F.P., R.B. Pearce, and R.L. Mitchell. 1985. Physiology of crop plants. Ames. Iowa University Press.

Horton, P. 2000. Prospects for crop improvement through the genetic manipulation of photosynthesis: morphological and biochemical aspects of light capture. Journal of Experimental Botany 51: 475-485. DOI: 10.1093/jexbot/51.suppl_1.475

Hubbart, S., S. Peng, P. Horton, Y. Chen, and E.H. Murchie. 2007. Trends in leaf photosynthesis in historical rice varieties developed in the Philippines since 1966. Journal of Experimental Botany 58: 3429-3438. DOI: 10.1093/jxb/erm192

IRRI. 2013. Standard evaluation system for rice (SES). International Rice Research Institute. Philipina.

Joshi, B.K. 2003. Heterosis in $\mathrm{F}_{1}$ rice hybrids. Journal of the Institute of Agriculture and Animal Science 24: 29-36.

Kartina, N., Y. Widyastuti, dan Satoto. 2014. Keragaan karakter agronomi padi hibrida baru. Buletin Plasma Nutfah 20: 59-64. DOI: 10.21082/blpn.v20n2.2014.p59-64

Kartina, N., B.P. Wibowo, Y. Widyastuti, dan Satoto. 2017. Pengujian daya hasil calon varietas padi hibrida. Prosiding Seminar Nasional Peripi 2017. Bogor 3 Oktober 2017. Hal. 246-254.

Lin, S.C. and L.P. Yuan. 1980. Hybrid rice breeding in China. Innovative Approaches to Rice Breeding. Selected papers from the 1979 International Rice Research Conference. Los Banos Philippines. P: 35-51.

Liu, C., X. Zhou, D. Chen, L. Li, J. Li, and Y. Chen. 2014. Natural variation of leaf thickness and its association to yield traits in indica rice. Journal of Integrative Agriculture 13: 316-325. DOI: 10.1016/S2095-3119(13)60498-0

Ntanos, D.A. and S.D. Koutroubas. 2002. Dry matter and $\mathrm{N}$ accumulation and translocation for Indica and Japonica rice under Mediterranean conditions. Field Crop Research 74: 93-101. DOI: 10.1016/S0378-4290(01)00203-9

Peng, S., F. Garcia, R. Laza, A. Sanico, R. Visperas, and K.G. Cassman. 1996. Increased N use efficiency using a chloropyhll meter on high yielding irrigated rice. Field Crop Research 47: 243-252. DOI: 10.1016/S0378-4290(01)00203-9 
Peng, S., K.G. Cassman, S.S. Virmani, J. Sheehy, and G.S. Khush. 1999. Yield potential trends of tropical rice since the release of IR8 and the challenge of increasing rice yield potential. Crop Science 39: 1552-1559.

Rahimi, M., B. Rabiei, H. Samizadeh, and A. K. Ghasemi. 2010. Combining ability and heterosis in rice (Oryza sativa L. ) cultivars. Journal of Agricultural Science Technology 12: 223-231.

Saidaiah, P., M.S. Ramesha, S.S. Kumar, and A. Geetha. 2012. Evaluation of rice hybrids for heterosis of yield and yield attributing traits over locations. Madras Agricultural Journal 99: 202-209.

Satoto, Y. Widyastuti, I.A. Rumanti, and Sudibyo. 2010. Yield stability and resistance to bacterial leaf blight and tungro of hybrid rice verieties Hipa 7 and Hipa 8. Penelitian Pertanian Tanaman Pangan 29: 129-135.

Sholekha, U., Kuswanto, dan N. Basuki. 2015. Analisis daya gabung galur mandul jantan dan heterosis pada 12 padi hibrida (Oryza sativa L.). Jurnal Produksi Tanaman 3: 225-232.

Thorat, B.S., R.L. Kunkerkar, and T.A. Bagkar. 2017. Studies on heterosis for yield and its contributing traits in hybrid rice (Oryza sativa L.). International Journal of Chemical Studies 5: 712.
Tiwari, D.K., P. Pandey, S.P. Giri, and J.L. Dwivedi. 2011. Heterosis studies for yield and its components in rice hybrids using CMS system. Asian Journal of Plant Sciences 10: 29-42. DOI: 10.3923/ajps.2011.29.42

Virmani, S.S., B.C. Viraktamath, C.L. Casal, R.S. Toledo, M.T. Lopez, and J.O. Monaldo. 1997. Hybrid rice breeding manual, International Rice Research Institute, Phillipines.

Widyastuti, Y. and Satoto. 2012. Yield stability and adaptability of five hybrids rice at Central Java. Jurnal Penelitian Pertanian Tanaman Pangan 31: 87-92.

Xiong, D., J. Chen, T. Yu, W. Gao, X. Ling, Y. Li, S. Peng, and J. Huang. 2015. SPAD based leaf nitrogen estimation is impacted by environmental factors and crop leaf characteristics. Scientific Reports 5(13389): 1-11. DOI: 10.1038/srep13389

Yoshida, S. 1972. Physiological aspects of grain yield. Annual Review of Plant Physiology 23: 437-464.

Zhi-Yuan, H., Q.Bing-ran, Lv. Qi-ming, F. Xi-qin, X. Ye-yun, and Y. Long-ping. 2015. Heterosis expression of hybrid rice in natural and short day length conditions. Rice Science 22: 81-88. DOI: 10.1016/j.rsci.2015.05.010 